\title{
Medical students' attitudes to medical ethics education
}

\author{
Nadia H. Saied \\ From the Department of Community Medicine, College of Medicine, University of Mosul, Mosul, Iraq. \\ Correspondence: Nadia H. Saied. allsaied@yahoo.com.
}

(Ann Coll Med Mosul 2013; 39 (2): 101-106).

Received: $24^{\text {th }}$ Jun. 2012; Accepted: $23^{\text {th }}$ Apr. 2013.

\section{ABSTRACT}

Objective: The aim of the study is to investigate medical students' attitudes and opinions regarding medical ethics education.

Subjects and methods: The study was conducted in the College of Medicine, University of Mosul during the academic year 2011-2012. A cross-sectional study design was adopted with a self-administered questionnaire form distributed to medical students in the $5^{\text {th }}$ and $6^{\text {th }}$ undergraduate grades.

Results: Of 150 respondents, the majority (82\%) considered medical ethics teaching for medical students an important issue, and $69.3 \%$ agreed that medical ethics teaching would influence the attitudes and behaviors of doctors, and improve patient-doctor relationship. However, only $40 \%$ had general interest in learning more about medical ethics. Two thirds (64.8) of students were confident with their ability to recognize a significant ethical problems in clinical practice. Only $36 \%$ knew how to proceed when a patient is mentally incompetent. Conclusion: Medical students have a low positive attitude about the medical ethics teaching, and they may not be adequately prepared to meet the challenges of clinical practice. There should be incorporation of creative and integrated ethics curriculum to start in the first medical grade, with emphasis on ethical aspect of daily medical practice.

$$
\text { مواقف طلبة كلية الطب تجاه تعليم أخلاقيات الطب }
$$

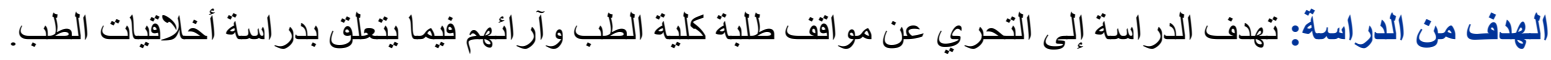

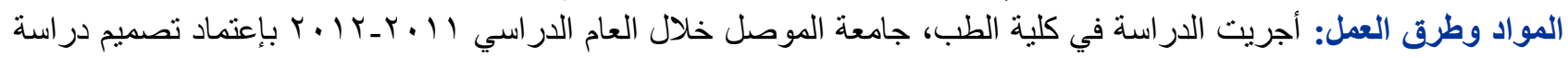

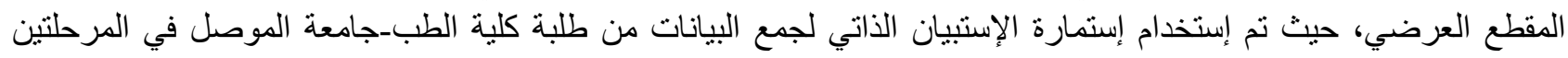

$$
\text { الخامسة و السادسة. }
$$

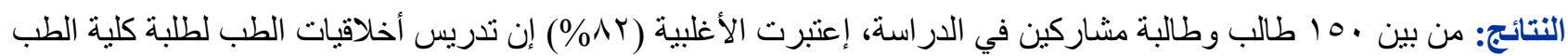

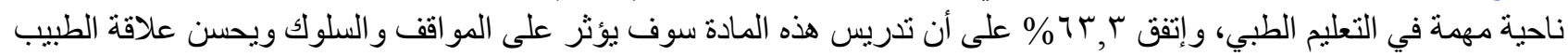

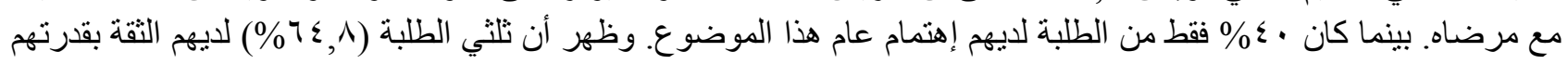

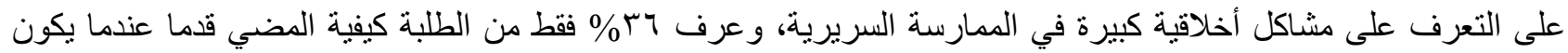
المريض غير مؤهل عقليا. الاستنتاجات: توصلت هذه الدراسة إلى أن طلبة كلية الطب كان لهم موقف أقل إيجابية حول تدريس أخلاقيات الطب وقد لايكونوا

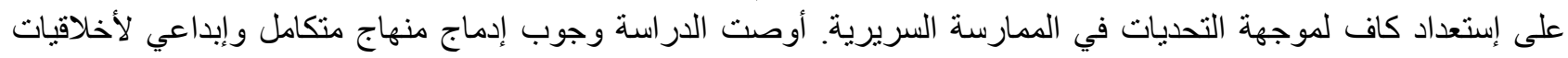
الطب منذ المرحلة الأولى مع التركيز على الجانب الأخلاقي في مجال الممارسة الطبية اليومية.

\section{INTRODUCTION}

$\mathrm{G}$ lobally, there was a great emphasis on medical ethics (MEs) which has been subjected to scientific and clinical teaching. ${ }^{1-4}$ In 1999, the World Medical Association "strongly recommended" to medical schools all over the world that teaching MEs and human rights should 
be compulsory in their curricula. ${ }^{5}$ Furthermore, the World Health Organization (WHO) recommended that MEs curriculum should install in the student knowledge, skills and attitudes the necessary educational materials to guide their conduct and decision making as practicing doctors. ${ }^{6}$ There is no doubt that teaching MEs will sensitize students and increase their awareness about the importance of human side of medicine, and provide the students with relevant tool to recognize and analyze ethical dilemmas arising in clinical practice, ${ }^{2,7}$ which relates not only to curriculum content and delivery but also appropriate assessment. ${ }^{8}$ Yet, there has been a diversity of goals set and methods used in MEs education. In general there is no single best model for MEs education. ${ }^{9}$ Previous studies indicated that medical students are not totally satisfied with a purely technical scientific medical education. There is a greater emphasis on the art of medicine, which would include clinical judgment, practical wisdom, and moral sensitivity. ${ }^{2,9}$

The topic of MEs was included in the curriculum of College of Medicine, University of Mosul in 2002. Nevertheless, students reaction, views and insight are important to ensure delivery of a curriculum that of interest and relevance to them. ${ }^{8}$ And it is essential to ensure that students attain the minimum knowledge base required for an appropriate undergraduate ethics education. ${ }^{10}$ Furthermore, students perspective is considered an important component in the evaluation of medical education ${ }^{11}$ thereby, the students should be invited to provide feedback in order to modify the curriculum according to their need and interest. $^{12}$ One of the most commonly used instruments for evaluating teaching is studentbased questionnaires because students are the principal receivers of instruction, their points of view have proven extremely useful. ${ }^{13}$ Accordingly, the present study aims to investigate medical students' attitudes regarding MEs teaching process in the College of Medicine, University of Mosul in addition to their suggestions for the most preferences regarding teaching and assessments methods.

Medical ethics together with the basis of professional behavior are given to the $4^{\text {th }}$ year medical students in the College of Medicine, University of Mosul, in form of formal lectures by the academics of the Departments of Community
Medicine and Forensic Medicine. The subject covers 30 hours during one academic year; teaching language used is Arabic. Assessment of the student's knowledge included 2 examinations, midyear and final. The examinations included short essays and problem solving questions.

\section{SUBJECTS AND METHODS}

The study was conducted in the College of Medicine, University of Mosul during the academic year 2011-2012. A cross-sectional study design was adopted. Students were requested to participate in this study by filling a selfadministered questionnaire. The questionnaire form was prepared by the author through literature review of several standardized questionnaire forms. ${ }^{8,9,14}$ The form focused on three main domains related to students' attitudes, opinions about MEs teaching, their confidence in relation to specific ethical issues in clinical settings, and their preferences for methods of teaching and assessment of MEs. The questionnaire form was distributed to all $5^{\text {th }}$ and $6^{\text {th }}$ grades medical students $(n=307)$. The students were met by the author to discuss the purpose of the study, to inform them that participation was optional and to reassure them that there will be no consequences for no-participation. The answers of the students were categorized in three groups: agree, don't know, and disagree. Data obtained were presented in appropriate tables, dealt with in a suitable computer program using (MINITAB) version 11.5 and demonstrated in the form of percentages.

\section{RESULTS}

One hundred and fifty forms were returned with a response rates of $63 \%$ and $34 \%$ for the $6^{\text {th }}$ and $5^{\text {th }}$ medical grades respectively, with an overall response rate of $(48.9 \%)$.

Table 1 shows distribution of study participants according to study grade, sex and frequency of attendance to MEs lectures. Two third of study sample were from the $6^{\text {th }}$ grade $(66.0 \%)$, similarly $(66.0 \%)$ of the sample were females. The study showed that one half $(48.0 \%)$ of the students were attending MEs lectures for few times; with one third $(31.0 \%)$ reported either none or minimal attendance.

Table 2 reveals that $82 \%$ of students considered MEs teaching for medical students an important aspect of medical education, and $69.3 \%$ agreed 
about the influence of MEs teaching on the attitude and behavior of doctors, hence improves patientdoctor relationship. However, only $40 \%$ had general interest in learning more about MEs. The proportion of those who gave I don't know answers varied between $10.7 \%$ for the $1^{\text {st }}$ item to $37.3 \%$ for the $5^{\text {th }}$ item.

Table 3 demonstrates that $64.6 \%$ of students were confident with their ability to recognize a significant ethical problem in clinical practice, and about half of them $(54.7 \%)$ have the ability to give reasons to their colleagues in support of their decision pertaining to matters of clinical ethics. While only $36 \%$ knew how to proceed when a patient is mentally incompetent. On the other hand almost one half $(48.0 \%)$ of students did not know whether they have the ability to reach a sound decision when facing ethical problems in clinical practice. Similarly $47.3 \%$ was given to the item related to the assessment of patient's capacity to make informed decision about his/her health care.

In Table 4 students rated case-studies with discussion group and clinically integrated methods as the most preferred teaching methods $(72.7 \%)$; while only $37.3 \%$ preferred lectures. Regarding the assessment methods, $72.7 \%$ preferred multiple choice questions followed by clinical supervision (70.7\%). About one third (30.7\%) preferred projects or papers.

Table 1. Characteristics of the study population.

\begin{tabular}{lll}
\hline \multicolumn{1}{c}{$\mathbf{N}=\mathbf{1 5 0}$} & No. & $\%$ \\
\hline $\begin{array}{l}\text { Students in the } 5^{\text {th }} \text { class } \\
\text { Students in the } 6^{\text {th }} \text { class }\end{array}$ & 51 & 34 \\
Sex & 99 & 66 \\
$\quad$ Male & 60 & 40 \\
$\quad$ Female & 90 & 60 \\
\hline Attendance to MEs lectures & & \\
$\quad$ Frequent & 31 & 20.7 \\
$\quad$ Sometimes & 72 & 48.0 \\
$\quad$ None or Minimal & 47 & 31.3 \\
\hline
\end{tabular}

Table 2. Students' attitude concerning MEs teaching $(n=150)$.

\begin{tabular}{|c|c|c|c|c|}
\hline & Items & $\underset{\%}{\text { Agree }}$ & $\begin{array}{c}\text { Don't } \\
\text { know } \\
\%\end{array}$ & $\begin{array}{c}\text { Disagree } \\
\%\end{array}$ \\
\hline 1 & $\begin{array}{l}\text { Medical ethics teaching for } \\
\text { medical students is } \\
\text { important aspect of medical } \\
\text { education. }\end{array}$ & 82.0 & 10. 7 & 7.3 \\
\hline 2 & $\begin{array}{l}\text { Medical ethics education in } \\
\text { a formal course are crucial } \\
\text { to good patient care. }\end{array}$ & 68.7 & 18.7 & 12.6 \\
\hline 3 & $\begin{array}{l}\text { Medical ethics teaching } \\
\text { should be integrated } \\
\text { horizontally \& vertically } \\
\text { within the medical } \\
\text { curriculum. }\end{array}$ & 60.0 & 32.0 & 8.0 \\
\hline 4 & $\begin{array}{l}\text { Medical teachers from } \\
\text { clinical disciplines is } \\
\text { required to obtain a } \\
\text { certified qualification in } \\
\text { MEs. }\end{array}$ & 57.3 & 33.3 & 9.4 \\
\hline 5 & $\begin{array}{l}\text { I have a general interest in } \\
\text { learning more about MEs. }\end{array}$ & 40.0 & 37.3 & 22.7 \\
\hline 6 & This topic is relevant to me. & 56.0 & 30.7 & 13.3 \\
\hline 7 & $\begin{array}{l}\text { Medical ethics education } \\
\text { made me more aware of } \\
\text { the complexity of the } \\
\text { practice of medicine. }\end{array}$ & 56.7 & 32.0 & 11.3 \\
\hline 8 & $\begin{array}{l}\text { The teaching of MEs. } \\
\text { enable me to engage with } \\
\text { contemporary ethical } \\
\text { issues. }\end{array}$ & 52.0 & 32.7 & 15.3 \\
\hline 9 & $\begin{array}{l}\text { Medical ethics teaching } \\
\text { would influence the attitude } \\
\text { and behavior of doctors } \\
\text { and improve patient-doctor } \\
\text { relationship. }\end{array}$ & 69.3 & 17.3 & 13.4 \\
\hline
\end{tabular}

Table 3. Students' confidence with ethical conflict $(n=150)$.

\begin{tabular}{|c|c|c|c|c|}
\hline & Items & $\begin{array}{c}\text { Agree } \\
\%\end{array}$ & $\begin{array}{c}\text { Don't } \\
\text { know } \\
\%\end{array}$ & $\begin{array}{c}\text { Disagree } \\
\%\end{array}$ \\
\hline 1 & $\begin{array}{l}\text { I have the ability to } \\
\text { recognize significant } \\
\text { ethical problems in } \\
\text { clinical practice. }\end{array}$ & 64.7 & 33.3 & 2.0 \\
\hline 2 & $\begin{array}{l}\text { I have the ability to } \\
\text { reach sound decision } \\
\text { when facing ethical } \\
\text { problems in clinical } \\
\text { practice. }\end{array}$ & 44.0 & 48.0 & 8.0 \\
\hline 3 & $\begin{array}{l}\text { I have the ability to give } \\
\text { reasons to my } \\
\text { colleagues in support of } \\
\text { my decision pertaining } \\
\text { to matters of clinical } \\
\text { ethics. }\end{array}$ & 54.7 & 35.3 & 10.0 \\
\hline 4 & $\begin{array}{l}\text { I know how to assess a } \\
\text { patient's capacity to } \\
\text { make informed decision } \\
\text { about his/ her health } \\
\text { care. }\end{array}$ & 41.3 & 47.3 & 11.4 \\
\hline 5 & $\begin{array}{l}\text { I know how to proceed } \\
\text { when a patient is } \\
\text { mentally in competent. }\end{array}$ & 36.0 & 41.3 & 22.7 \\
\hline 6 & $\begin{array}{l}\text { I have the ability to } \\
\text { communicate bad news } \\
\text { to a patient. }\end{array}$ & 42.0 & 43.3 & 14.7 \\
\hline
\end{tabular}


Table 4. Students' opinions regarding teaching and assessment methods of MEs $(n=150)$.

\begin{tabular}{|c|c|c|c|c|c|}
\hline \multirow{3}{*}{ Learning methods } & \multicolumn{4}{|c|}{ Student's responses } & \multirow{3}{*}{$\begin{array}{c}\text { P- } \\
\text { value* }\end{array}$} \\
\hline & \multicolumn{2}{|c|}{ Agree } & \multicolumn{2}{|c|}{ Disagree } & \\
\hline & No. & $\%$ & No. & $\%$ & \\
\hline 1- Lectures & 55 & 37.3 & 95 & 62.7 & 0.001 \\
\hline 2- Seminars & 68 & 45.3 & 82 & 54.7 & 0.288 \\
\hline $\begin{array}{l}\text { 3-Case-studies- } \\
\text { discussion group }\end{array}$ & 109 & 72.7 & 41 & 27.3 & 0.000 \\
\hline 4- Role play & 106 & 71.3 & 44 & 28.7 & 0.000 \\
\hline 5-Clinically integrated & 109 & 72.7 & 41 & 27.3 & 0.000 \\
\hline \multicolumn{6}{|l|}{ Assessment methods } \\
\hline 1- Projects or papers & 46 & 30.7 & 104 & 69.3 & 0.000 \\
\hline $\begin{array}{l}\text { 2-Multiple choice } \\
\text { question (MSQ) }\end{array}$ & 109 & 72.7 & 41 & 27.3 & 0.000 \\
\hline $\begin{array}{l}\text { 3-OSCE and } \\
\text { standardized patient } \\
\text { interviews }\end{array}$ & 100 & 66.7 & 50 & 33.3 & 0.000 \\
\hline $\begin{array}{l}\text { 4- Case studies with } \\
\text { short written answers }\end{array}$ & 75 & 50 & 75 & 50 & 1.000 \\
\hline 5-Clinicalsupervision & 105 & 70.7 & 45 & 29.3 & 0.000 \\
\hline
\end{tabular}

Regarding an open question about opinions to improve the ME curriculum, the following comments were given by the students:

- Having yearly course from the first year. $\left(6^{\text {th }}\right.$ grade, male student).

- It is better to learn this from our doctors' experience in their practical life. $\left(6^{\text {th }}\right.$ grade, male student)

-The training should be at hospital with a real patient to feel the situation better. $\left(6^{\text {th }}\right.$ grade, female student)

-The best thing is the clinical rounds, MEs was taught in form of formal lectures, but the practice was different from the main ethical principles. The same student added that patients must be informed and educated that they are admitted to a teaching hospital and may be submitted to students' examination. ( $6^{\text {th }}$ grade, male student).

\section{DISCUSSION}

The response rate was almost $50 \%$. In fact, such low response rate could be due to lack of interest of students in the topic which may be related to unsupportive institutional culture and students' dissatisfaction with the topic. Several studies were faced with such low response (rates varied from $28 \%$ to $67 \%$ ). ${ }^{9,14-16}$

Eighty two percent of the respondents considered that MEs teaching is an important aspect of medical education. About $69.3 \%$ thought that teaching MEs would influence the attitude and behavior of doctors and improve doctor-patient relationship. Unfortunately less than half (40\%) had general interest in learning more about MEs.
Results of other studies was somewhat variable, Roberts et al ${ }^{14}$ study carried out in 2004 at the University of New Mexico School of Medicine, the respondents strongly affirmed the appropriateness of ethics education which improved clinical care and interpersonal skills. Higher rate was seen in a study conducted in Queen Elizabeth Hospital in Barbados in 2006, which revealed that medical students were generally very positive about the importance of ethical knowledge (over $90 \%$ ). ${ }^{17}$ While Johnston and Haughton ${ }^{8}$ at King's College, London School in 2007, revealed that $87 \%$ of medical students thought that the subject was important and $50 \%$ were interested in MEs education. Furthermore, in a work conducted in the University of New Mexico in 2009, depicted the agreement among medical students on the effect of MEs education in helping professionals to better recognize ethical issues, clarify value-laden choices, improve patient care and clinical decision making. ${ }^{15}$ Similarly a study of King Saud bin Abdul-Aziz University for Health Sciences in 2010, showed that $95 \%$ of students expressed their strong agreement on the importance of their learning biomedical ethics and $53 \%$ considered the subject as interesting. ${ }^{18}$ However, Chin et $a{ }^{16}$ in 2011 ; found that $78.8 \%$ of students felt that ethics education is important requirement of medical education. As well $83.5 \%$ of undergraduates in West Bengal medical school agreed that awareness of ethics was important for their future professions. ${ }^{19}$ These variations in attitudes regarding MEs education, to a certain extent are related to the fact that positive or negative attitudes are affected by MEs teaching process.

Confidence is a precursor of clinical ethical competence, ranging from confidence in knowing something to confidence in performing something. ${ }^{16}$ In the current study only $64.6 \%$ of respondents were confident in having the ability to recognize a significant ethical problem in clinical practice. About half of the students $(54.6 \%)$, were confident in having the ability to give reasons to their colleagues in support of their decision regarding matters of clinical ethics. Only one third $(36 \%)$ said that they are able to proceed when a patient is mentally incompetent. These rates were much lower than the study of Chin et al ${ }^{16}$ in Singapore which showed $(90.5 \%, 91.5 \%$ and $78.4 \%)$ to similar statements respectively. 
Unfortunately, these low rating of present study students indicate that the current curriculum of MEs does not fulfill the students' requirement regarding this subject or the students are not motivated about the importance of this curriculum.

In the current work students were rating their preferred teaching methods as, case studies with discussion group and clinically integrated, followed by role play; while the least preferred method was formal lecturing, which is the adopted method of teaching this subject in the study setting. This result is comparable with other studies. In the study of Roberts et al ${ }^{14}$ in 2004 the respondents rated clinical approaches (role modeling by faculty, clinical rounds, interaction with patients and case conferences) as the most effective, while formal didactic approaches (grand round presentation and lectures) are only somewhat effective. Similarly in a study on postgraduate bioethics education in Canada in 2006, $87 \%$ of chief residents felt that case based small group discussion was the most effective teaching method, while $82 \%$ indicated that the least effective methods were didactic lectures and open ended discussion. ${ }^{20}$ In the study of New Mexico University ${ }^{15}$ the students strongly agreed that ethics training should include group discussion, consultation and guidance on the ethical and scientific designs of specific protocols, and interaction with institutional review Considering the preferred assessment methods in the present study, students highly rated multiple choice questions followed by clinical supervision and project or essay examination. Johnston and Haughton $^{8}$ found that students indicated a strong preference for assessment by way of rolling case studies with short-written answer. However, the study of Ozan et al $^{9}$ in Turkey in 2010, demonstrated that students rated the following in descending sequence: essay questions, multiple choice questions, projects or papers, Objective Structured Clinical Examination (OSCE), and lastly standardized patient interview.

\section{CONCLUSION}

Students appeared to be less adequately prepared to meet the challenges of clinical practice. There should be incorporation of creative and integrated ethics curriculum starting in the first medical grade, with emphasis on ethical aspect of daily medical practice.

\section{REFERENCES}

1. Ashcroft R, Baron D, Benatar S, Bewley S. Teaching medical ethics and law within medical education: a model for the UK core curriculum. J M E 1998;24:188192.

2. Sliverberg LI. Survey of medical ethics in US medical schools: a descriptive study. JAOA 2000;100 (6):373378.

3. Shidfar F, Sadeghi S, Kaviani A. A survey of medical ethics education in Iran medical faculties. Iran J Allergy Asthma Immunol 2007; 6(5):47-51.

4. Selvakumar D, Joseph LBM. The importance of including bio-medical ethics in the curriculum of health education institutes. Education for Health 2004;17(1):9396.

5. Moodley K. Teaching and learning ethics. JME 2007; 33:673-677.

6. WHO, Regional Office for South-East Asia. Module for teaching medical ethics to undergraduates.2009:1.

7. Al-Mahroos F, Bandaranayake R C. Teaching medical ethics in medical schools. Ann Saudi Med 2003,23:1-4

8. Johnston C, Haughton P. Medical students' perception of their ethics teaching. JME 2007;33(7):418422.

9. Ozan S, Timbil S, Semin S, Musal B. Interns' perceptions on medical ethics education and ethical issues at the Dokuz Eylul University School of Medicne in Turkey. Education for Health 2010; 23(3): 1-11.

10. Goldie J, Schwartz L, Morrison J. A process evaluation of medical ethics education in the first year of a new medical curriculum. Medical Education 2000; 34:468-473.

11. Yacoub A A- $\mathrm{H}$, Ajeel $\mathrm{N}$ A-H. Teaching medical ethics in Basra: perspective of students and graduates. EMHJ 2000; 6(4):687-692

12. Roff $S$, Preece $P$. Helping medical students to find their moral compasses: ethics teaching for second and third year undergraduates. JME 2004;30:487-489.

13. Valle R, Alaminos I, Contreras E, Salas L E,Tomasini $P$ and Varela M. Student questionnaire to evaluate basic medical science teaching (METEO-B). Rev Med I MSS 2004; 42(5):405-411.

14. Roberts LW, Hammond KG, Geppert CM, Warner TD. The positive role of professionalism and ethics training in medical education: A comparison of medical student and resident perspectives. Academic Psychiatry J 2004;28:170-180.

15. Lehrmann JA, Hoop J, Hammond KG, Roberts LW. Medical Students' Affirmation of Ethics Education. Academic Psychiatry J. 2009;33:470-477.

16. Chin JL, Voo TC, Abdulkarim S, Chan YH and Campbell AV. Evaluating the effect of an integrated medical ethics curriculum on first year students. Annals Academy of Medicine 2011; 40:4-18.

17. Walrond ER, Jonnalagadda R, Hariharan S, Moseley HSL. Knowledge, attitudes and practice of medical students at the Cave Hill Campus in relation to ethics and law in healthcare. West Indian med J 2006;55(1): 42-7.

18. Al-Haqwi Al, Al-Shehri AM. Medical students' evaluation of their exposure to the teaching of ethics. Medical Education J. 2010;17(1):41-45. 
19. Chatterjee B, Sarkar J. Awareness of medical ethics among undergraduates in a West Bengal medical school. Indian JME 2012; 9(2):93-100.
20. Levin AV, Berry S, Kassardjian CD, Howard F, McKneally M. Ethics teaching is as important as my clinical education: A survey of participants in residency education at a single university. UTMJ 2006;84:60-63. 